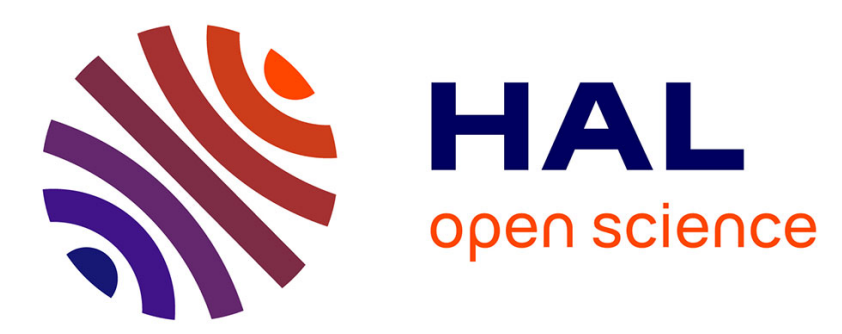

\title{
Soundness of in situ lipid biomarker analysis: Early effect of heavy metals on leaf fatty acid composition of Lactuca serriola
}

Marina Le Guédard, Olivier Faure, Jean-Jacques Bessoule

\section{- To cite this version:}

Marina Le Guédard, Olivier Faure, Jean-Jacques Bessoule. Soundness of in situ lipid biomarker analysis: Early effect of heavy metals on leaf fatty acid composition of Lactuca serriola. Environmental and Experimental Botany, 2012, 76, pp.54-59. 10.1016/j.envexpbot.2011.10.009 . hal-00667913

\section{HAL Id: hal-00667913 https://hal.science/hal-00667913}

Submitted on 27 Apr 2012

HAL is a multi-disciplinary open access archive for the deposit and dissemination of scientific research documents, whether they are published or not. The documents may come from teaching and research institutions in France or abroad, or from public or private research centers.
L'archive ouverte pluridisciplinaire HAL, est destinée au dépôt et à la diffusion de documents scientifiques de niveau recherche, publiés ou non, émanant des établissements d'enseignement et de recherche français ou étrangers, des laboratoires publics ou privés. 


\title{
Soundness of in situ lipid biomarker analysis: Early effect of heavy metals on leaf fatty acid composition of Lactuca serriola
}

\author{
MARINA LE GUÉDARD ${ }^{(1) *}$, OLIVIER FAURE(2), JEAN-JACQUES BESSOULE(1)
}

(1) Université de Bordeaux Segalen, Laboratoire de Biogenèse Membranaire, UMR-CNRS 5200 ; 146, rue Léo Saignat, Case 92, F-33076, France

(2) Ecole Nationale Supérieure des Mines de Saint Etienne, Centre SPIN ; Département GSE ; 158 Cours Fauriel - 42023 Saint-Étienne Cedex 2, France

\begin{abstract}
In previous studies we proposed the plant leaf fatty acid composition, and more precisely the ratio $\mathrm{C} 18: 3 /(\mathrm{C} 18: 0+\mathrm{C} 18: 1+\mathrm{C} 18: 2)$ as a tool to diagnose soil contamination ex situ. These studies led us to normalize this parameter as a biomarker of soil quality using Lactuca sativa growing under controlled conditions as the plant model species. The evaluation of the toxic effects of pollutants is more difficult to grasp in a real and more complex environment. Hence we developed a study to test the hypothesis that plant leaf fatty acid composition could be used also as a reliable tool to diagnose soil contamination in situ. We tested whether Lactuca serriola (prickly lettuce) could be used as a plant model species for such studies, primarily because it is widely distributed in various European countries and recorded at different habitats, and regarded as an ancestor of the cultivated lettuce L. sativa that was used for ex situ experiments. The results show that the lipid biomarker values were significantly lower in leaves of $L$. serriola grown on a metallurgic landfill soil than in leaves of plants harvested on surrounding countryside areas. To determine whether the value of the lipid biomarker in $L$. serriola leaves could be correlated to the soil metal content, we also measured the metal content of the soil corresponding to the rhyzospheric areas from where the prickly lettuce leaves were harvested. The results of the Principal Component Analysis (PCA) show that the lipid biomarker is negatively correlated with both $\mathrm{Ni}$ and $\mathrm{Cr}$ content. Moreover, these results show that the lipid biomarker values measured in situ were repeatable from year to year, confirm that this biomarker measured in situ would provide an early indication of a plant's exposure to metal, and could be therefore used to facilitate or strengthen the diagnosis of soil contamination.
\end{abstract}

Keywords:

Lactuca serriola; Lipid biomarker; Fatty acids; Metallurgical landfill; Chromium; Nickel

\section{Introduction}

Soil is at the interface between geosphere, hydrosphere and biosphere and fulfils multiple environmental (e.g. storage, filtering and transformation), economic (e.g. source of raw materials, food production and biomass), social and cultural (e.g. platform of human activity, landscape support, cultural heritage) functions. Soil is also an ecosystem in its own right involving a huge quantity and variety of living organisms. As a result, soil appears as an essential resource for human societies and ecosystems. Hence, anthropogenic activities of various origins (agricultural, urban and industrial) that cause severe impacts on the health and/or the functioning of ecosystems have become a worrying problem. To enable the sustainable development of societies, it is now necessary to ensure soil protection. To initiate,

\footnotetext{
* Corresponding author : marina.le-guedart@biomemb.u-bordeaux2.fr
} 
follow, and ensure appropriate protective actions and management of soils, it is advisable to develop indicators to identify and quantify the disturbances and changes in soil quality, and to further determine the impacts on ecosystems. Currently, characterization and evaluation of soil pollution is mainly based on physicochemical analysis. However, to evaluate global environmental stress (e.g. chemical pollution, physical condition of soil, biological changes, etc.), biological indicators are necessary in complement to physicochemical analysis (Commission to the Council, the European Parliament, 2006). Among these biological indicators, biomarkers must be developed and used. A biomarker is defined as an observable and/or measurable change in an organism at a molecular, biochemical, cellular, physiological, or behavioral level, related to its exposure to at least one chemical pollutant (Lagadic et al., 1997). These biomarkers must be able to detect early effects that may eventually become irreversible damage on the individual, community or ecosystem.

We have previously developed a biomarker of exposure, which have been used successfully for assessing the ecotoxicity of complex soils (Verdoni et al., 2001, Le Guédard et al., 2008 and [Le Guédard and Bessoule, 2011). We showed that the leaf fatty acid composition of tomato or lettuce was modified when plants were grown on metal contaminated soil in a phytotronic chamber. More precisely, it was shown that the $\mathrm{C} 18: 3 /(\mathrm{C} 18: 0+\mathrm{C} 18: 1+\mathrm{C} 18: 2)$ ratio (called "lipid biomarker") decreases.

Although the results of numerous tests give proof that the lipid biomarker is a consistent and powerful tool to measure soil quality ex situ (Le Guédard and Bessoule, 2011), one potential limitation to the data is the controlled conditions under which the previous studies were carried out. In a real environment, the complex mixtures of pollutants, combined with physical alterations of habitat and climatic conditions can render experimental evaluation of the toxic effects of pollutants more difficult. Therefore, one of our aims was to test the hypothesis that the lipid biomarker could be also successfully used in situ to diagnose soil contamination.

The site investigated in the framework of the "Bioindicator" programme funded by ADEME (French Environment and Energy Management Agency) was a highly polluted metallurgical landfill. Among the plant species growing in this site, Lactuca serriola (prickly lettuce) was chosen as the plant model species because the edible lettuce (Lactuca sativa) was used successfully in our previous studies carried out ex situ (Le Guédard et al., 2008 and Le Guédard and Bessoule, 2011). In the present paper, the leaf fatty acid composition of $20 \mathrm{~L}$. serriola plants harvested on the metal-contaminated landfill was compared to the fatty composition of 20 prickly lettuce leaves harvested on areas located in the vicinity of the landfill. Then, to determine whether the value of the lipid biomarker in L. serriola leaves could be correlated to the soil metal content, the fatty acid composition of 27 prickly lettuce leaves harvested on the metal-contaminated landfill, was compared to the metal content of the rhyzospheric soils where the harvested prickly lettuce were growing.

\section{Material and methods}

\section{II.1. Biological features of $L$. serriola}

L. serriola is a winter annual or biennial plant of the Asteraceae family whose distribution area extends mainly in temperate Eurasia. This species is a common weed present throughout France, colonizer of disturbed habitats like roadsides, vacant lots, slopes and other dry places. $L$. serriola is regarded as a progenitor and part of the primary gene pool of cultivated lettuce, $L$. sativa L. (Lebeda et al., 2001 and Oregon State University, 1998). This plant has strong selffertilizing ability (Lebeda et al., 2001 and Mejías, 1993) and is primarily pollinated by insects. It flowers from July until September. Regarding lipid metabolism, as other asteraceae (Mongrand et al., 1998), L. serriola is a C18:3 plant. In other words, L. serriola leaves do not contain 16:3 fatty acid (on control soil, they contained: $20.25 \pm 1.97 \%$ of $16: 0,2.27 \pm 0.38 \%$ of $16: 1,1.57 \pm 0.22 \%$ of $18: 0,1.91 \pm 0.31 \%$ of $18: 1,9.74 \pm 1.96 \%$ of $18: 2$ and $64.27 \pm 1.97 \%$ of $18: 3$ fatty acids $(n=20))$. 


\section{II.2. Site description}

L. serriola leaves were harvested on a highly polluted metallurgical landfill located near Lyon (Rhône, France), behind an iron and steel factory which was still in activity. The landfill covers about 15 ha and has been used since 1850 to deposit iron and steel foundry wastes. As a result, the soil of this site is not native from the underlying bedrock, but is a metalliferous soil. Because the site was still in activity, vegetation cover with both trees and herbaceous species on this site was very heterogeneous due to engine traffic and new waste deposits. The site, located about an altitude of $250 \mathrm{~m}$, is under a temperate continental climate with mean annual temperature of $10{ }^{\circ} \mathrm{C}$, including minimal and maximal values ranging from $-26{ }^{\circ} \mathrm{C}$ to $+41^{\circ} \mathrm{C}$. The annual precipitation average is $750 \mathrm{~mm}$.

\section{II.3. Soil analyses}

Soil samples collected were dried at $60^{\circ} \mathrm{C}$ for $48 \mathrm{~h}$, sieved to $2 \mathrm{~mm}$ and ground to pass a 250$\mu \mathrm{m}$ mesh sieve before analyses. The $\mathrm{pH}$ value of the soil was determined in deionise water using a 1:2 soil:water ratio according to the NF ISO 10390 procedure (AFNOR, 1999). The total $\mathrm{Na}^{+}$content was determined using cobaltihexamine chloride. Results showed a homogenous $\mathrm{Na}^{+}$content on various areas of the metallurgical landfill soil, and evidenced a low amount of $\mathrm{Na}^{+}: 0.0207 \pm 0.005 \mathrm{~mol} / \mathrm{kg}$, which represented less than $0.1 \%(\mathrm{w} / \mathrm{w})$ of $\mathrm{NaCl}$ in this soil. Concentrations of heavy metals in various extracts were performed by ICP-OES, after aqua regia extraction as previously described (AFNOR, 1994 and Remon et al., 2005). Limits of detection were $0.06,0.14,1.17,2.05,2.38$ and $15.51 \mu \mathrm{g} \mathrm{l}^{-1}$ for $\mathrm{Zn}, \mathrm{Cd}, \mathrm{Cr}, \mathrm{Cu}, \mathrm{Pb}$ and $\mathrm{Ni}$, respectively. To check the analytical precision, randomly chosen samples (about 20\% of the total number) were measured in triplicate. The relative standard deviation was routinely between 1 and $8 \%$, and never higher than 10\%. For quality control of soil analyses for total metals, certified reference soils NCS DC 73323 and 73006 from the China National Analysis Center for Iron and Steel were included in the batch of samples submitted to aqua regia extraction. Average recoveries $(\mathrm{n}=6)$ were $83,73,76,85,104$ and $99 \%$ for $\mathrm{Zn}, \mathrm{Cd}, \mathrm{Cr}, \mathrm{Cu}, \mathrm{Pb}$ and $\mathrm{Ni}$, respectively.

\section{II.4. Fatty acid extraction, analysis and identification}

About $10-100 \mathrm{mg}$ of fresh tissue were placed in screw-capped tubes containing $1 \mathrm{ml}$ of methanol, $2.5 \% \mathrm{H}_{2} \mathrm{SO}_{4}(\mathrm{v} / \mathrm{v})$. After $1 \mathrm{~h}$ of heating at $80{ }^{\circ} \mathrm{C}, 1.5 \mathrm{ml} \mathrm{of} \mathrm{H}_{2} \mathrm{O}$ and $0.75 \mathrm{ml}$ of hexane were added. Fatty acid methyl esters (FAMEs) were extracted into hexane by vigorous shaking, after a two-phase system was established by centrifugation $(1500 \times \mathrm{g}, 5 \mathrm{~min})$. The methyl esters were analysed by gas chromatography (Hewlett-Packard 5890 series II, Agilent, Waldbronn, Germany) on a $15 \mathrm{~m} \times 0.53 \mathrm{~mm}$ Carbowax column (Altech, Deerfield, IL, USA) with flame ionization detection and helium as carrier gas. The temperature program was as follows: the initial temperature of 160 was held for $1 \mathrm{~min}$, followed by a $20{ }^{\circ} \mathrm{C} / \mathrm{min}$ ramp to 190 ${ }^{\circ} \mathrm{C}$ and a second ramp of $5{ }^{\circ} \mathrm{C} / \mathrm{min}$ to $210{ }^{\circ} \mathrm{C}$, and maintained at this temperature for a further 6 min (total run time $13 \mathrm{~min}$ ) (Le Guédard et al., 2008). Routinely, fatty acids were identified by comparing their retention times with standards (Sigma Chemical, St. Louis, MO, USA). To analyse data in the same way as previous ex situ experiments (Le Guédard et al., 2008 and Le Guédard and Bessoule, 2011), results are expressed as the $\mathrm{C} 18: 3 /(\mathrm{C} 18: 0+\mathrm{C} 18: 1+\mathrm{C} 18: 2)$ ratio.

\section{II.5. Statistical analysis}

Statistical treatments were performed with the software XLSTAT. The Shapiro-Wilk test was used to check normal distribution. When the variables follow a normal distribution, parametric statistical tests (Student's t-test, Pearson's correlation) were used, whereas non-parametric statistical test (Spearman's rank correlation coefficient) was used when the distribution of the variables was not normal. Pearson's correlations were used to test the associations between the plant size and the lipid biomarker values measured on the leaves from lettuce harvested on the surrounding countryside or on the metallurgical landfill. Lipid biomarker and metal content values were analysed by Principal Component Analysis (PCA) from covariance matrix. 
Environmental and Experimental Botany, 2012, 76, 54-59,

doi: 10.1016/j.envexpbot.2011.10.009

\section{Results}

III.1. Lipid biomarker of $L$. serriola harvested on the metallurgical site or on the surrounding countryside areas

The lipid biomarker was successfully used ex situ for assessing the ecotoxicity of complex soils (Verdoni et al., 2001 and Le Guédard et al., 2008). In order to determine whether it could also be a powerful tool in situ, a first set of analyses was carried out with $L$. serriola plants harvested both on a contaminated site and on areas located in the surrounding countryside of this site (control area). The contaminated site under study is a highly metallurgical landfill that contains high levels of $\mathrm{Cr}, \mathrm{Zn}, \mathrm{Ni}$ and $\mathrm{Pb}$ (concentrations ranging from 601 to $1393 \mathrm{mg} \mathrm{kg}^{-1}$ ) (Remon, 2006). The metal content in this soil is therefore greatly higher than the content observed in the soil of the control area (Table 1). The leaf fatty acid compositions of 40 prickly lettuces found on this metallurgical site (20 plants) and on the surrounding countryside areas (20 plants) were determined. Figure 1 shows the distribution of $\mathrm{C} 18: 3 /(\mathrm{C} 18: 0+\mathrm{C} 18: 1+\mathrm{C} 18: 2)$ ratio values for plants harvested both on the metallurgical landfill and on the surrounding countryside areas. The mean of $\mathrm{C} 18: 3 /(\mathrm{C} 18: 0+\mathrm{C} 18: 1+\mathrm{C} 18: 2)$ ratios (usually used ex situ as a "lipid biomarker") was significantly ( $\mathrm{p}=0.008$; Student's t-test) lower in leaves of $L$. serriola grown on the metallurgical landfill $(4.10 \pm 1.08)$ than when grown on the surrounding countryside areas $(5.02 \pm 1.00)$. These results are in agreement with those previously obtained ex situ with L. sativa (Le Guédard et al., 2008 and Le Guédard and Bessoule, 2011) and highlight an adverse effect of wasteland soil on plants.

Plants under analysis had highly variable size, ranging from 0.1 to $1.2 \mathrm{~m}$. To determine whether lipid biomarker values were correlated to plant size, a Pearson correlation analysis test was carried out (Figure 2). Result clearly showed that, whatever the soil on which lettuces grown, there was no correlation between the lipid biomarker values and the plant size (surrounding countryside: $R=0.392, p=0.087$; metallurgical landfill: $R=-0.077, p=0.755$ ). Similarly, the lipid biomarker values were independent of the vegetative coverage of the harvesting location, the level of sun exposure or the stage of development of the harvested plant (vegetative, prebloom, bloom) (data not shown). However, the lipid biomarker seemed to vary more widely according to the areas sampled within the contaminated site. Significantly higher values of $5.32,5.31$ and 6.09 were obtained for three plants harvested at the border of the site, and it was possible that this area was less contaminated than the other areas sampled further into the contaminated site. Such an assumption was further investigated.

III.2. Correlation between the lipid biomarker measured with $L$. serriola and the metal content in soils

Three leaves per L. serriola plant were sampled again one year later (also mid of June) from each of nine areas of the metallurgical site. The analysis of fatty acid composition showed high repeatability of the measurements since the mean of the 27 lipid biomarker values was $4.18 \pm$ 0.84 , closed to the values $(4.10 \pm 1.08)$ determined a year ago on the same site. In addition, as observed after the first sampling campaign, the lipid biomarker values (5.61, 5.86 and 5.37) were higher on an area located at the site border, than on the other landfill areas.

To determine whether the lipid biomarker values were correlated to the soil metal contents, soil samples corresponding to the various rhizospheric areas of plants were collected simultaneously to the lettuce leaf harvest. Measurements of the total metal content in soils of the metallurgical site (Table 2) showed that $\mathrm{Cr}, \mathrm{Zn}, \mathrm{Ni}$, and $\mathrm{Cu}$ were the most abundant heavy metals in the soil. These metals were present at a concentration range from 504 to $1346 \mathrm{mg}$ $\mathrm{kg}^{-1}$ as observed in previous studies from the same site (Remon, 2006). This indicates that the average metal content on this site did not greatly vary as a function of time. Moreover, the performed chemical analysis confirmed that the area located on the border site and displaying the highest lipid biomarker values (L4) was the area containing the lowest metal amounts. A statistical analysis by PCA was further carried out. Result (Table 3) shows that the lipid biomarker is significantly ( $\mathrm{p}<0.05$; Spearman's rank correlation coefficient) negatively correlated with $\mathrm{Ni}$ and $\mathrm{Cr}$, but did not correlate with other metal $(\mathrm{Cd}, \mathrm{Cu}, \mathrm{Pb}$ and $\mathrm{Zn}$ ) contents. In addition, a significant positive correlation is observed between $\mathrm{Cr}$ and $\mathrm{Ni}$. The correlation 
circle of the two first principal components analysis is shown in Figure 3. The first two principal components account for $83.46 \%$ of the total variation (eigenvalue $>1$ ). $\mathrm{Ni}$ and $\mathrm{Cr}$ are correlated with the first component (representing $46.27 \%$ of the total variation). These variables are positively correlated with the first principal component. The second component (37.19\% of the total variation) is mainly linked to $\mathrm{Cd}, \mathrm{Pb}$ and $\mathrm{Zn}$ with a positive correlation. Thus, in the correlation circle, $\mathrm{Ni}$ and $\mathrm{Cr}$ form a cluster of correlated variables, whereas $\mathrm{Zn}, \mathrm{Pb}$ and Cd taking a more independent position. As regards the lipid biomarker, is negatively correlated with the first principal component, and as a consequence with $\mathrm{Cr}$ and $\mathrm{Ni}$. Thus, all together, these results clearly indicate a relationship between low (resp. high) lipid biomarker values and high (resp. low) $\mathrm{Cr}$ and $\mathrm{Ni}$ content. Nevertheless, since $\mathrm{Cr}$ and $\mathrm{Ni}$ contents were highly correlated, it is not possible to determine which one of these metals (or both of them) impacted the fatty acid composition of $L$. serriola leaves.

\section{Discussion}

The aim of this study was to determine whether the fatty acid composition of $L$. Serriola leaves could be used successfully as a biomarker of soil contamination in situ. We showed that $L$. serriola grown on a contaminated landfill displayed lower lipid biomarker values than when grown on the areas located in the vicinity of the site. This control area was located at 1-2 km from the metallurgic landfill and at the same altitude (i.e. in the same geographical area), and climate conditions were the same in both of these contexts. Nevertheless, it cannot be excluded that a difference in a parameter other than the metal content between the countryside and metallurgical landfill soils was responsible for the decrease in the biomarker values. For this reason, we further determined whether within the same location (i.e. on the same soil), the biomarker values were correlated to the metal content of the rhyzospheric areas. These analyses highlighted a clear relationship between lipid biomarker values and (some) metal content in the soil of the various areas of the metallurgic landfill. Hence, it appeared that the results obtained with $L$. serriola in situ were in perfect accordance with those previously obtained with $L$. sativa grown in a phytotronic chamber (Le Guédard et al., 2008). Actually, results obtained ex situ with $S$. lycopersicum and $L$. sativa showed that the decrease in lipid biomarker values mainly resulted from a decrease in the percentage of linolenic acid (C18:3) (Verdoni et al., 2001 and Le Guédard et al., 2008). Such a decrease in the amount of triunsaturated fatty acids in higher plants was also observed for tomato seedlings grown in culture solution containing copper or cadmium (Ouariti et al., 1997 and Djebali et al., 2005), as well as for pepper and rape seedlings grown in nutrient solution supplemented with Cd (Jemal et al., 2000 and Ben Youssef et al., 2005). Interestingly, $\mathrm{Cu}$ and $\mathrm{Pb}$ did not induce change in the fatty acid composition of cultured lichens that do not contain tri (or more) unsaturated fatty acids (Guschina and Harwood, 2006), whereas Rhytidiadelphus squarrosus, a moss that contains high levels of polyunsaturated fatty acids (PUFAs), when obtained from a Pb-polluted site has significantly less PUFAs containing three or more double bonds (Guschina and Harwood, 2002). All together, these results highlight the fact that fatty acids containing at least three double bonds are more specifically targeted by heavy metal contamination. In agreement, the decrease in lipid biomarker values in leaves of $L$. serriola grown in situ on contaminated soils resulted from a decrease in the percentage of linolenic acid (C18:3): $64.3 \pm 2.0 \%(\mathrm{n}=20)$ and $58.1 \pm 3.4 \%(\mathrm{n}=20)$ on the surrounding countryside areas and on the landfill soil, respectively. In higher plants, tri-unsaturated fatty acids are mainly associated with chloroplast lipids, and more precisely with thylakoid membrane lipids. Indeed, the tri-unsaturated fatty acids content in photosynthetic membranes is crucial to various parameters such as on chloroplast ultrastructure, thylakoid membrane protein and chlorophyll content, electron transport rates, and the thermal stability of the photosynthetic membranes (Hugly et al., 1989). In this study, it is shown that the decrease in the lipid biomarker on contaminated soil is not related to the size of the lettuce or the level of sun exposure or the stage of development. Thus, since photosynthesis provides the material necessary for plant growth and development, our results suggest that metals in soil could initially induce an early alteration on chloroplast membranes, which could lead later to the disruption of photosynthetic function and as a result 
inhibit plant growth. In other words, these results show that the lipid biomarker measure an early effect of contaminants that has not yet had an impact on plant physiology such as plant growth.

To cause toxic effects, metals ions must be transferred from soils to plants. However, this transfer depend on many parameters including the heavy metal mobility, which depends on factors (Violante et al., 2010) such as the type of metals, their concentration in the soil and their bioavailability, modulated by the presence of organic matter, $\mathrm{pH}$, redox potential, concentration of other elements. Once in the plant, the impact of metal-ion toxicity on biochemical processes depends on the plant species, the time exposure, and metal concentration in the plant (Sanitá di Toppi and Gabbrielli, 1999). The contaminated site under study was a landfill that contains high levels of $\mathrm{Cu}, \mathrm{Ni}, \mathrm{Zn}$ and $\mathrm{Cr}(504,582,1091$ and $1346 \mathrm{mg}$ $\mathrm{kg}^{-1}$, respectively) that were largely attributable to industrial activities. Among these metals, the decrease in the lipid biomarker values in situ is positively solely correlated with $\mathrm{Cr}$ and $\mathrm{Ni}$ contents. Thus, these results suggest that (i) $\mathrm{Cr}$ and $\mathrm{Ni}$ are the only bioavailable metals in the contaminated soil, (ii) these metals are the only ones which induce change in the leaf fatty acid composition of $L$. serriola, or (iii) these metals are in competition with other metals in soil, and thus may inhibit their absorption. $\mathrm{Cr}$ does not play any role in plant metabolism, whereas $\mathrm{Ni}$ is an essential micronutrient for normal plant growth and development (Brown et al., 1987). Nevertheless, at high concentrations both $\mathrm{Ni}$ and $\mathrm{Cr}$ have various adverse effects such as inhibition of growth and development, induction of leaf chlorosis, necrosis and wilting and disruption of photosynthesis in various plant species (Sun and Wu, 1998, Gajewska et al., 2006, Tripathy et al., 1981, Boominathan and Doran, 2002, Boisvert et al., 2007, Van Assche and Clijsters, 1983 and Dixit et al., 2002). In our case, the absence of a difference in plant size between the contexts and the absence of leaf necrosis provide a misleading visual indication of contamination at the site. In cases like this, the lipid biomarker would make it possible to diagnose soil $\mathrm{Ni}$ and $\mathrm{Cr}$ contamination early.

To summarize, the present study show that the lipid biomarker values measured in situ were repeatable from year to year, and confirm that this biomarker would provide an early indication of a plant's exposure to metal in situ, and could be therefore used in addition to other well-known biomarkers to facilitate or strengthen the diagnosis of soil contamination. In addition, it was of interest to demonstrate that $L$. serriola can be used as plant model in such studies because this species is widely distributed in Europe, both in wild and urban habitats (Lebeda et al., 2001 and Lebeda et al., 2007).

\section{Acknowledgements}

This work received substantial support from the Agence pour le Développement et la Maîtrise de l'Energie (ADEME, France). Cécile Grand (ADEME) and Antonio Bispo (ADEME) are particularly acknowledged.

\section{References}

AFNOR, 1994

AFNOR, 1994. Soil Quality - Soils, Sediments, Sewerage Plant Sludges - Solubilizing of Metallic Trace Elements (Cd, Co, Cr, Cu, Mn, Ni, Pb, Zn) by Acid Attacks - Norme NF X 31-151. Recueil de normes françaises - Qualité des sols (Ed. Afnor), pp. 123-129.

AFNOR, 1999

AFNOR, 1999. Soil Quality - Determination of pH - Norme NF ISO 10390. Recueil Normes - Qualité des sols (Ed. Afnor), pp. 339-347.

Ben Youssef et al., 2005

N. Ben Youssef, I. Nouairi, S. Ben Temime, W. Taamalli, M. Zarrouk, M.H. Ghorbal, D. Ben Miled Daoud; Cadmium effects on lipid metabolism of rape (Brassica napus L.), C. R. Biol., 328 (2005), pp. 745-757 


\section{Boisvert et al., 2007}

S. Boisvert, D. Joly, S. Leclerc, S. Govindachary, J. Harnois, R. Carpentier; Inhibition of the oxygen-evolving complex of photosystem II and depletion of extrinsic polypeptides by nickel, Biometals, 20 (2007), pp. 879-889

Boominathan and Doran, 2002

R. Boominathan, P.M. Doran; Ni-induced oxidative stress in roots of the $\mathrm{Ni}$ hyperaccumulator, Alyssum bertolonii, New Phytol., 156 (2002), pp. 205-215

Brown et al., 1987

P.H. Brown, R.M. Welch, E.E. Cary; Nickel: A micronutrient essential for higher plants, Plant Physiol., 85 (1987), pp. 801-803

Commission to the Council, 2006

Commission to the Council, the European Parliament, the European Economic and Social Committee and the Committee of the Regions, 2006. Thematic Strategy for Soil Protection. COM 231. Brussels, Belgium.

Dixit et al., 2002

V. Dixit, V. Pandey, R. Shyam; Chromium ions inactivate electron transport and enhance superoxide generation in vivo in pea (Pisum sativatum $L$ Cv: Azad) root mitochondria, Plant Cell Environ., 25 (2002), pp. 687-693

Djebali et al., 2005

W. Djebali, M. Zarrouk, R. Brouquisse, S. El Kahoui, F. Limam, M.H. Ghorbel, W. Chaibi; Ultrastructure and lipid alterations induced by cadmium in tomato (Lycopersicon esculentum) chloroplast membranes, Plant Biol. (Stuttg), 7 (2005), pp. 358-368

Gajewska et al., 2006

E. Gajewska, M. Sklodowska, M. Slaba, J. Mazur; Effect of nickel on antioxidative enzyme activities, proline and chlorophyll contents in wheat shoots, Biol. Plant, 50 (2006), pp. 653-659

Guschina and Harwood, 2002

I.A. Guschina, J.L. Harwood; Lipid metabolism in the moss Rhytidiadelphus squarrosus (Hedw.) Warnst. from lead-contaminated and non-contaminated populations, J. Exp. Bot., 53 (2002), pp. 455-463

Guschina and Harwood, 2006

I.A. Guschina, J.L. Harwood; Lead and copper effects on lipid metabolism in cultured lichen photobionts with different phosphorus status, Phytochemistry, 67 (2006), pp. 1731-1739

Hugly et al., 1989

S. Hugly, L. Kunst, J. Browse, C. Somerville; Enhanced thermal tolerance of photosynthesis and altered chloroplast ultrastructure in a mutant of arabidopsis deficient in lipid desaturation, Plant Physiol., 90 (1989), pp. 1134-1142

Jemal et al., 2000

F. Jemal, M. Zarrouk, M.H. Ghorbal; Effect of cadmium on lipid composition of pepper,

Biochem. Soc. Trans., 28 (2000), pp. 907-910

Lagadic et al., 1997

L. Lagadic, T. Caquet, J.C. Amiard; Biomarqueurs en écotoxicologie: principes et définitions, In L. Lagadic, T. Caquet, J.C. Amiard, F. Ramade (Eds.), Biomarqueurs en Ecotoxicologie: Aspects Fondamentaux, Masson, Paris, France (1997), pp. 1-9

Le Guédard et al., 2008

M. Le Guédard, B. Schraauwers, I. Larrieu, J.J. Bessoule; Development of a biomarker for metal bioavailability: the lettuce fatty acid composition, Environ. Toxicol. Chem., 27 (2008), pp. 1147-1151

Le Guédard and Bessoule, 2011

Le Guédard, M., Bessoule, J.J.; Détermination des effets des polluants sur la flore. Effets des sols contaminés sur la composition en acides gras foliaires de Lactuca sativa. Qualité des sols. Projet de norme AFNOR. Commission T95E. (2011) 
Lebeda et al., 2001

A. Lebeda, I. Doležalová, E. Křristková, B. Mieslerová; Biodiversity and ecogeography of wild Lactuca spp. in some European countries, Genet. Res. Crop Evol., 48 (2001), pp. 153-164

Lebeda et al., 2007

A. Lebeda, I. Doležalová, E. Křístková, K.J. Dehmer, D. Astley, C.C.M. Van de Wiel, R. Van Treuren; Acquisition and ecological characterization of Lactuca serriola $L$. germplasm collected in the Czech Republic, Germany, the Netherlands and United Kingdom, Genet. Res. Crop Evol., 54 (2007), pp. 555-562

Mejías, 1993

J.A. Mejías; Cytotaxonomic studies in the Iberian taxa of the genus Lactuca

(Compositae), Bot. Helvet., 103 (1993), pp. 113-130

Mongrand et al., 1998

S. Mongrand, J.J. Bessoule, F. Cabantous, C. Cassagne; The C16:3/C18:3 fatty acid balance in photosynthetic tissues from 468 plant species, Phytochemistry, 49 (1998), pp. 1049-1064

Oregon State University, 1998

Oregon State University, Weed Science Program, 1998. Lactuca serriola (Prickly lettuce). Oregon State University, Extension, Research, and the Department of Crop and Soil Science, website: http://www.css.orst.edu/weeds/Prickly lettuce/biology.htm.

Ouariti et al., 1997

O. Ouariti, N. Boussama, M. Zarrouk, A. Cherif, M.H. Ghorbal; Cadmium- and copperinduced changes in tomato membrane lipids, Phytochemistry, 45 (1997), pp. 1343-1350

Remon et al., 2005

E. Remon, J.L. Bouchardon, B. Cornier, B. Guy, J.C. Leclerc, O. Faure; Soil characteristics, heavy metal availability and vegetation recovery at a former metallurgical landfill: implications in risk assessment and site restoration, Environ. Pollut., 137 (2005), pp. $316-323$

Remon, 2006

Remon, E.; Tolérance et accumulation des métaux lourds par la végétation spontanée des friches métallurgiques : vers de nouvelles méthodes de bio-dépollution. Thesis, (2006).

Sanitá di Toppi and Gabbrielli, 1999

L. Sanitá di Toppi, R. Gabbrielli; Response to cadmium in higher plants, Environ. Exp. Bot., 41 (1999), pp. 105-130

Sun and $\mathrm{Wu}, 1998$

E.J. Sun, F.Y. Wu; Along-vein necrosis as indicator symptom on water spinach caused by nickel in water culture, Bot. Bull. Acad. Sin., 39 (1998), pp. 255-259

Tripathy et al., 1981

B.C. Tripathy, B. Bhatia, P. Mohanty; Inactivation of chloroplast photosynthetic electrontransport activity by $\mathrm{Ni}^{2+}$, Biochim. Biophys. Acta: Bioenergetics, 638 (1981), pp. 22172224

Van Assche and Clijsters, 1983

F. Van Assche, H. Clijsters; Multiple effects of heavy metals on photosynthesis, In: R. Marcelle (Ed.), Effects of Stress on Photosynthesis, vol. 7 Nijhoff/Junk, The Hague (1983), pp. 371-382

Verdoni et al., 2001

N. Verdoni, M. Mench, C. Cassagne, J.J. Bessoule; Fatty acid composition of tomato leaves as biomarkers of metal-contaminated soils, Environ. Toxicol. Chem., 20 (2001), pp. $382-388$

Violante et al., 2010

A. Violante, V. Cozzolino, L. Perelomov, A.G. Caporale, M. Pigna; Mobility and bioavailability of heavy metals and metalloids in soil environments, J. Soil. Sci. Plant Nutr., 10 (2010), pp. 268-292 


\section{Figures}

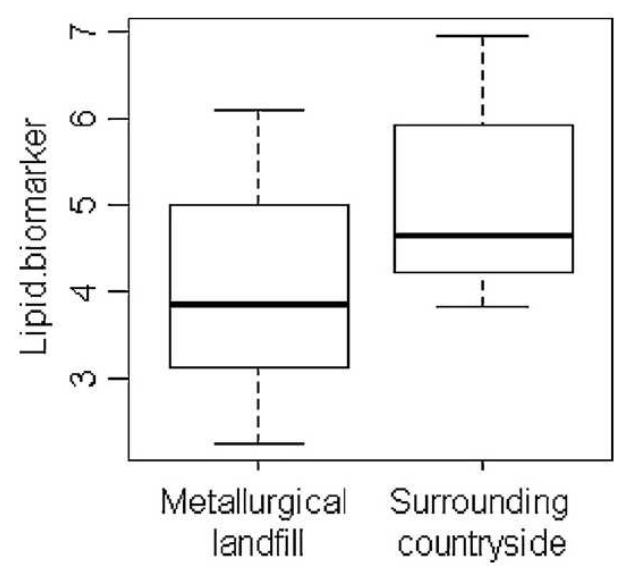

Figure 1: Distribution of lipid biomarker (C18:3/(C18:o + C18:1 + C18:2) ratio) values of lettuce leaves harvested on the surrounding countryside and on the metallurgical landfill. 40 lettuce leaves were harvested on the metallurgical site (2O analyses) and on the surrounding countryside areas (2O analyses). The fatty acid composition of lettuce leaves was determined as described in Material and Methods section. The Tukey box plot show the distribution of the values of the $(C 18: 3 /(C 18: 0+C 18: 1+C 18: 2)$ ratios. C18:o = stearic acid; C18:1 = oleic acid; C18:2 = linoleic acid; C18:3 = linolenic acid.
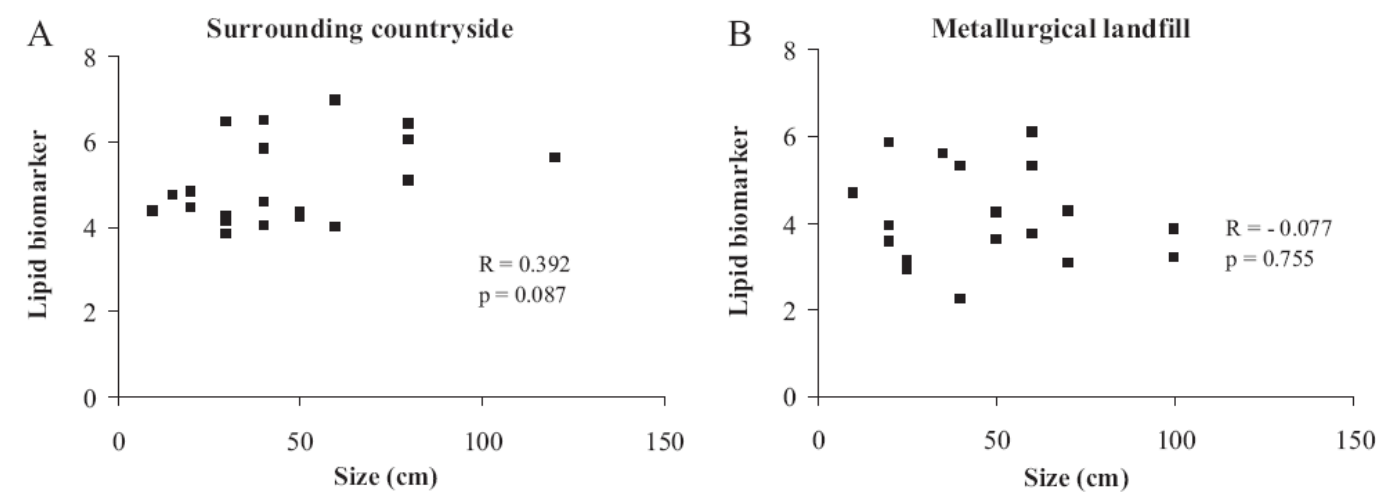

Figure 2: Correlation between the lipid biomarker and the lettuce size. Size and lipid biomarker values of lettuces harvested on the surrounding countryside (A) and on the metallurgical site (B). R: Pearson's correlation coefficient. p: significance of the Pearson's correlation coefficient.
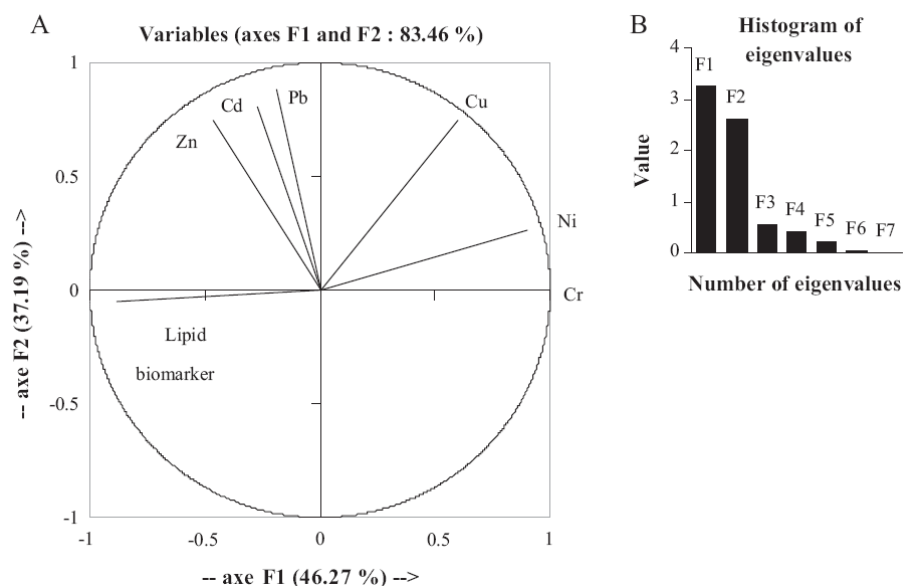

Figure 3: Correlation circle and associated vectors of 7 variables (lipid biomarker, $\mathrm{Cu}, \mathrm{Zn}, \mathrm{Ni}, \mathrm{Cr}, \mathrm{Pb}, \mathrm{Cd}$ ) calculated in the two first principal components of the PCA (Principal Component Analysis). (A) Correlation circle and associated vectors of variables calculated in the two first principal components of the Principal Component Analysis (PCA; the first axis [F1] explained $46.27 \%$ and the second axis [F2] 37.19\% of the variance). (B) The eigenvalues of sample-based PCA showing variances of the first 7 principal components. 
Environmental and Experimental Botany, 2012, 76, 54-59,

doi: 10.1016/j.envexpbot.2011.10.009

\section{Tables}

Table 1: Metal concentrations measured from nine soil samples of the control area.

\begin{tabular}{|c|c|c|c|c|c|c|}
\hline \multicolumn{7}{|c|}{ Metals ( $\left.\mathrm{mg} \mathrm{kg}^{-1}\right)$ in total ${ }^{a}$ fraction } \\
\hline & $C d$ & $\mathrm{Cr}$ & $\mathrm{Cu}$ & $N i$ & $P b$ & $Z n$ \\
\hline & n.d. & 70 & 39 & 50 & 40 & 178 \\
\hline & n.d. & 115 & 69 & 66 & 101 & 203 \\
\hline & n.d. & 82 & 44 & 49 & 60 & 148 \\
\hline & n.d. & 73 & 48 & 48 & 51 & 179 \\
\hline & n.d. & 75 & 47 & 48 & 56 & 185 \\
\hline & n.d. & 163 & 60 & 101 & 297 & 177 \\
\hline & n.d. & 74 & 46 & 46 & 59 & 157 \\
\hline & n.d. & 92 & 48 & 59 & 57 & 140 \\
\hline & n.d. & 105 & 46 & 58 & 63 & 153 \\
\hline Median & n.d. & 82 & 47 & 50 & 59 & 177 \\
\hline
\end{tabular}

${ }^{a}$ : Extracted with aqua regia. n.d.: not detected

Table 2: Soil concentrations of metals and corresponding lipid biomarker values measured on nine areas of the metallurgical landfill.

\begin{tabular}{|c|c|c|c|c|c|c|c|}
\hline \multirow{2}{*}{ Location } & \multicolumn{6}{|c|}{ Metals (mg $\left.\mathrm{kg}^{-1}\right)$ in total fraction } & \multirow{2}{*}{$\begin{array}{c}\text { Lipid } \\
\text { biomarker }\end{array}$} \\
\hline & $C d$ & $\mathrm{Cr}$ & $\mathrm{Cu}$ & $\mathrm{Ni}$ & $\mathrm{Pb}$ & $Z n$ & \\
\hline$L 1$ & 39.11 & 1130.74 & 4707.01 & 572.69 & 2071.53 & 3530.04 & $4 \cdot 52$ \\
\hline$L_{2}$ & 18.88 & 960.64 & 443.94 & 518.62 & 778.72 & 4470.05 & 4.92 \\
\hline$L_{3}$ & 11.47 & 3893.95 & 1080.04 & 2078.25 & 186.41 & 779.78 & 3.05 \\
\hline L4 & 8.19 & 998.47 & $157 \cdot 38$ & 336.47 & 100.06 & 373.87 & 5.61 \\
\hline$L_{5}$ & 5.84 & 4085.41 & 983.38 & 2667.99 & 659.27 & 692.43 & 4.28 \\
\hline$L 6$ & 8.56 & 1562.17 & 564.02 & 1523.62 & 868.38 & 1402.92 & 4.66 \\
\hline$L_{7}$ & 4.52 & 779.62 & 285.63 & 222.33 & 237.88 & 1573.04 & 4.77 \\
\hline$L 8$ & 2.72 & 3187.46 & 372.21 & 591.70 & 143.40 & 756.62 & 3.78 \\
\hline L9 & 2.80 & 3164.03 & $587 \cdot 43$ & 1312.31 & 229.05 & 470.44 & 4.16 \\
\hline Median & $7 \cdot 33$ & 1346.46 & 503.98 & 582.20 & 336.66 & 1091.35 & 4.52 \\
\hline
\end{tabular}

a: Extracted with aqua regia. 
Environmental and Experimental Botany, 2012, 76, 54-59,

doi: 10.1016/j.envexpbot.2011.10.009

Table 3: Spearman correlation coefficient matrix between the lipid biomarker variable and the metal concentration variables ( $\mathrm{Cd}, \mathrm{Cr}, \mathrm{Cu}, \mathrm{Ni}, \mathrm{Pb}$ and $\mathrm{Zn}$ ).

\begin{tabular}{|c|c|c|c|c|c|c|c|}
\hline & Lipid biomarker & $\mathrm{Cd}$ & $\mathrm{Cr}$ & $\mathrm{Cu}$ & $\mathrm{Ni}$ & $\mathrm{Pb}$ & $\mathrm{Zn}$ \\
\hline Lipid biomarker & 1 & 0.283 & $-\mathbf{0 . 8 1 7}$ & -0.583 & $-\mathbf{0 . 7 0 0}$ & 0.183 & 0.200 \\
\hline $\mathrm{Cd}$ & & 1 & -0.233 & 0.467 & -0.017 & 0.583 & 0.600 \\
\hline $\mathrm{Cr}$ & & & 1 & 0.550 & $\mathbf{O . 9 1 7}$ & -0.183 & -0.467 \\
\hline $\mathrm{Cu}$ & & & & 1 & $\mathbf{0 . 6 6 7}$ & 0.517 & 0.217 \\
\hline $\mathrm{Ni}$ & & & & & 1 & 0.117 & -0.267 \\
\hline $\mathrm{Pb}$ & & & & & & 1 & $\mathbf{0 . 7 1 7}$ \\
\hline $\mathrm{Zn}$ & & & & & & & 1 \\
\hline
\end{tabular}

In bold, significant values (except diagonal) at alpha $=0.050$ (two-tailed test). 